\title{
Evaluation of care of dentoalveolar trauma
}

\author{
Luiz Fernando FARINIUK', Maria Helena de SOUSA², Vânia Portela Dietzel WESTPHALEN', Everdan CARNEIRO', \\ Ulisses X. SILVA NETO' ${ }^{1}$, Liliane ROSKAMP ${ }^{3}$, Ana Égide CAVALI²
}

\footnotetext{
1- DDS, MSc, PhD Professor of Endodontics, Department of Dentistry, Pontifical Catholic University of Paraná, Curitiba, PR, Brazil.

2- DDS, MSc, Professor of Endodontics, Department of Dentistry, Pontifical Catholic University of Paraná - PUCPR.

4- DDS, MSc, Pontifical Catholic University of Paraná, Curitiba, PR, Brazil.
}

Corresponding address: Prof. Dr. Luiz Fernando Fariniuk - Rua Imaculada Conceição, 1115 - Prado Velho - 80215-000 - Curitiba - Paraná - Brazil - Phone: 5541 3077-2294 - e-mail: fariniuk@uol.com.br

Received: January 11, 2009 - Modification: May 09, 2009 - Accepted: October 05, 2009

\section{ABSTRACT}

\begin{abstract}
O bjectives: The aim of this study was to evaluate cases of dental trauma treated at the specialized center of Pontifical Catholic University of Paraná, Curitiba, Brazil, during a period of 2 years. Material and methods: A total of 647 patients were evaluated and treated between 2003 and 2005. Data obtained from each patient were tabulated and analyzed as to gender, age, etiology, time elapsed after the injury, diagnosis (type of trauma), and affected teeth. Results: The results revealed that male individuals aged 7 to 13 years presented the highest prevalence of injury, and falling was the main causal factor. In most cases, the time elapsed between the accident and the first care ranged from 4 to $24 \mathrm{~h}$. A total of 1,747 teeth were affected, with higher incidence of concussion/subluxation and coronal fracture, followed by lateral luxation and avulsion. The permanent maxillary central incisors were the most commonly affected teeth. Conclusion: The frequency and causes of dentoalveolar trauma should be investigated for identification of risk groups, treatment demands and costs in order to allow for the establishment of effective preventive measures that can reduce the treatment duration and costs for both patients and oral health services.
\end{abstract}

Key words: Tooth injury. Dentoalveolar trauma. Examination. Prevalence.

\section{INTRODUCTION}

Dentoalveolar traumas are observed and treated in dental clinics. Their severity depends on the energy of impact and direction of the causal agent, as well as on the resistance of the tissues surrounding the traumatized teeth, which are more susceptible at the anterior region ${ }^{11}$, along with immunological factors, particularly in cases of avulsion and replantation ${ }^{15}$. Situations such as car, sports and working accidents, and falling are the most common reasons for dental traumatism $7,11,20$.

Facial and dental injuries have become an epidemiological health problem and may be more frequent than periodontal disease and caries in a near future, causing social, esthetic and psychological disturbances to the patients ${ }^{3,14,18}$. In the present study, an epidemiological evaluation of patients attending the Dentoalveolar Trauma Care Service of the Pontifical Catholic University of Paraná, Brazil, between 2003 and 2005, was undertaken to better analyze the requirements of emergency assistance.

\section{MATERIAL AND METHODS}

Sixty hundred and forty seven patients with dentoalveolar trauma were treated at the Dentoalveolar Trauma Care Service of the Pontifical Catholic University of Paraná, Brazil, between 2003 and 2005. Informed consent was obtained from all patients for collection of data from their dental charts, and the study protocol was approved by the University Research Ethics Committee (Protocol \#1406). Information referring to gender, age, etiology, period of the year and hour of occurrence, time elapsed after the injury, diagnosis (type of trauma) and most affected teeth, were retrieved, plotted and presented in tables for further analysis.

\section{RESULTS}

In the 3-year period of this study with a sample of 647 patients, dentoalveolar traumas occurred more frequently in males, accounting for $64.1 \%$ of cases, with mean age of 16.09 years. The most affected age range was 7 to 13 years $(31.4 \%)$, 
Table 1- Age range gender divided into female and male

\begin{tabular}{lrrrrrrr}
\hline Gender & \multicolumn{9}{c}{ Age range (percentage) } & \multicolumn{2}{c}{ Total } \\
& $\mathbf{0 - 6}$ & $\mathbf{7 - 1 3}$ & $\mathbf{1 4 - 2 1}$ & $\mathbf{2 2 - 2 9}$ & $\mathbf{3 0 - 4 0}$ & $\mathbf{> 4 0}$ & \\
\hline & & & & & & & \\
Female & $56(24.1)$ & $82(35.3)$ & $35(15.1)$ & $34(14.7)$ & $19(8.2)$ & $6(2.6)$ & $232(100)$ \\
Male & $62(14.9)$ & $121(29.2)$ & $118(28.4)$ & $62(14.9)$ & $37(8.9)$ & $15(3.6)$ & $415(100)$ \\
Total & $118(18.2)$ & $203(31.4)$ & $153(23.6)$ & $96(14.8)$ & $56(8.7)$ & $21(3.2)$ & $647(100)$ \\
\hline
\end{tabular}

Table 2- Etiology of dental trauma

\begin{tabular}{lc}
\hline Etiology & $\mathbf{N}(\%)$ \\
\hline & \\
Car accident & $85(13.10)$ \\
Sports accident & $21(3.20)$ \\
Physical aggression & $74(11.40)$ \\
Running over & $26(4.00)$ \\
Frontal crash & $53(8.20)$ \\
Falling & $349(53.90)$ \\
Others & $23(3.60)$ \\
Unreported & $16(2.50)$ \\
Total & $647(100.00)$ \\
\hline
\end{tabular}

Table 3- Time elapsed between the accident and the first care

\begin{tabular}{ll}
\hline Time elapsed & $\mathbf{N}(\%)$ \\
\hline$<1$ hour & $110(103)$ \\
$1-2 \mathrm{~h}$ & $223(214)$ \\
$2-4 \mathrm{~h}$ & $197(129)$ \\
$>4$ to $24 \mathrm{~h}$ & $134(121)$ \\
Up to 7 days & $202(210)$ \\
$>7$ days & - \\
unreported & $24(20)$ \\
total & $43(53)$ \\
\hline
\end{tabular}

Table 4- Frequency of each diagnosis of dental trauma

\begin{tabular}{lc}
\hline Diagnosis (type of trauma) & N (\%) \\
\hline Avulsion & $237(13.6)$ \\
Concussion/subluxation & $416(23.8)$ \\
\hline Extrusion & $110(6.3)$ \\
Crown fracture & $414(23.7)$ \\
Crown-root fracture & $29(1.7)$ \\
Bone fracture & $85(4.9)$ \\
Root fracture & $104(6.0)$ \\
Intrusion & $113(6.5)$ \\
\hline Lateral luxation & $239(13.7)$ \\
\hline Total & $1,747(100)$ \\
\hline
\end{tabular}

followed by 14 to 21 years (23.6\%) (Table 1 ). Analysis of the etiology of injuries revealed that falling, car accidents and physical aggression were the main causal factors (Table 2 ). With regard to the time elapsed after the injury until first care was
Table 5- Frequency of the different types of trauma to the permanent maxillary central incisors

\begin{tabular}{lc}
\hline Diagnosis (type of trauma) & $\mathbf{N}(\%)$ \\
\hline & \\
Avulsion & $141(15.2)$ \\
Concussion/subluxation & $220(23.7)$ \\
Extrusion & $56(6.0)$ \\
Crown fracture & $260(28.0)$ \\
Crown-root fracture & $11(1.2)$ \\
Bone fracture & $38(4.1)$ \\
Root fracture & $74(8.0)$ \\
Intrusion & $42(4.5)$ \\
Lateral luxation & $87(9.4)$ \\
Total & $929(100)$ \\
\hline
\end{tabular}

provided, $32.6 \%$ of the subjected sought treatment within 4 to $24 \mathrm{~h}$ after injury, followed by 2 to $4 \mathrm{~h}$ $(20.6 \%)$ (Table 3$)$. A total of 1,747 teeth were affected. Most injuries were concussion/subluxation $(23.8 \%)$, coronal fracture $(23.7 \%)$, followed by lateral luxation (13.7\%) and avulsion (13.6\%) (Table 4). The permanent maxillary central incisors were the most affected teeth (53.2\%), followed by the permanent maxillary lateral incisors (17.1\%) and the primary maxillary central incisors (10.3\%). The most frequent lesions in the permanent maxillary central incisors were coronal fracture $(28.0 \%)$, concussion/subluxation $(23.7 \%)$ and avulsion (15.2\%) (Table 5).

\section{DISCUSSION}

An analysis of investigations of dentoalveolar traumas reveals that comparisons are very complex due to the different research methodologies employed $^{8}$. The prevalence of dentoalveolar trauma varies according to the type of study, country where the study was conducted, and even different regions in a single country ${ }^{7}$. Statistics reveal that $4.2 \%$ to $36 \%$ of children, adolescents and young adults have already experienced dental trauma?.

In the present study, most traumas affected male individuals, as reported in other studies ${ }^{13,19,20}$. Boys are usually more susceptible to traumatic tooth injuries due to their greater involvement in 
sports activities, car accidents and fights ${ }^{12}$. The most frequently affected age range was 7 to 13 years, accounting for $31.4 \%$ of cases. Sakai, et al. ${ }^{16}$ (2005), found a higher incidence in children aged 0 and 3 years (34.42\%), followed by those in the $7-12$-year-old group (18.12\%). The most frequent etiologic agents were falls, car accidents and physical assaults, which agree with the findings of other studies $2,7,17$.

According to the diagnosis (type of trauma), there was higher incidence of concussion/subluxation, followed by coronal fracture, lateral luxation and avulsion. Some studies found different results ${ }^{4,5}$, yet others agree with the present findings ${ }^{12,20}$. The high rate of luxation and avulsion were probably related to the severity of injuries.

As far as the time elapsed after the trauma until first care was provided, $74.4 \%$ of patients seen by a dentist in the same day of the accident, in most after $4 \mathrm{~h}$. Only $5.9 \%$ of the cases were treated up to $1 \mathrm{~h}$ after the injury, which is probably due to the fact that dentists are not always the first health professionals assisting these patients, who often search for care at hospital emergency units. It has also been observed that decisions taken by health professionals, including dentists, are not always correct, which delays proper care and impairs the prognosis in medium and long term, due to the lack of knowledge of the management of dental trauma 5,10 .

Immediate care is required in cases of dentoalveolar trauma. This type of emergency situation often requires several sessions for treatment, continuity for investigation and even treatment of possible sequelae ${ }^{1,6}$.

The most affected teeth were the permanent maxillary central incisors, accounting for $53.2 \%$ of cases, which exhibited higher occurrence of coronal fracture, concussion/subluxation, and avulsion.

Some epidemiological studies are conducted at hospitals ${ }^{2}$, whereas others are conducted at Pediatric Dentistry clinics ${ }^{9}$. The present study was conducted at a specialized facility that treats only patients with dental trauma. This dentoalveolar trauma care service was created due to the gap existing in this type of care, especially concerning healthcare to the poor population.

\section{CONCLUSION}

The frequency and causes of dentoalveolar trauma should be investigated for identification of risk groups, treatment demands and costs in order to allow for the establishment of effective preventive measures that can reduce the treatment duration and costs for both patients and oral health services. Educational campaigns are needed in order to inform teachers, parents and health professionals about the best emergency measures, and reduce the time elapsed between the dental trauma and the first care.

\section{REFERENCES}

1- Al-Jundi SH. Type of treatment, prognosis, and estimation of time spent to manage dental trauma in late presentation cases at a dental teaching hospital: a longitudinal and retrospective study. Dent Traumatol. 2004;20:1-3.

2- Andreasen JO. Aetiology and pathogenesis of traumatic dental injuries. A clinical study of 1298 cases. Scand J Dent Res. 1970,78:329-42.

3- Andreasen JO, Andreasen FM. Incidence of dental trauma: quo vadis. Endod Dent Traumatol. 1990;6:78-80.

4- Andreasen JO, Andreasen FM. Textbook and color atlas of traumatic injuries to the teeh. 3rd ed. Saint Louis: Mosby; 1997. 5- Andreasen JO, Andreasen FM, Skeie A, Hjorting-Hansen E, Schwartz O. Effect of treatment delay upon pulp and periodontal healing of traumatic dental injuries - a review article. Dent Traumatol. 2002;18:116-28.

6- De Rossi M, De Rossi A, Queiroz AM, Nelson Filho P. Management of a complex dentoalveolar trauma: a case report. Braz Dent J. 2009;20(3):259-62.

7- García-Ballesta C, Pérez-Lajarín L, Castejón-Navas I. Prevalencia y etiología e los traumatismos dentales. Una revisión. RCOE. 2003;8:131-41.

8- Grimm S, Frazão P, Antunes JLF, Castellanos RA, Narvai PC. Dental injury among Brazilian schoolchildren in the state of São Paulo. Dent Traumatol. 2004;20:134-8.

9- Haaviko K, Rananen L. A folow-up study of injuries to permanent and primary teeth in children. Proc Finn Dent Soc. 1976;72:152-62. 10- Jackson NG, Waterhouse PJ, Maguire A. Factors affecting treatment outcomes following complicated crown fractures managed in primary and secondary care. Dent Traumatol. $2006 ; 22: 179-85$.

11- Kramer FP, Zembruski C, Ferreira SH, Feldens CA. Traumatic dental injuries in Brazilian preschool children. Dent Traumatol. 2003;19:299-303.

12- Panzarini SR, Pedrini D, Poi WR, Sonoda CK, Brandini DA, Castro JCM. Dental trauma involving root fracture and periodontal ligament injury: a 10-year retrospective study. Braz Oral Res. 2008;22(3):229-34.

13- Rocha MJC, Cardoso M. Traumatized permanent teeth in Brazilian children assisted at the Federal University of Santa Catarina, Brazil. Dent Traumatol. 2001;17:245-9.

14- Rodríguez JG. Diagnóstico y tratamiento de las fracturas coronarias: una revisión de la literatura. Acta Odontol Venez. 2004;42:209-12.

15- Roskamp L, Westphalen, VPD, Lima JHC, Carneiro E, Fariniuk LF, Silva Neto UX, et al. The influence of atopy in the prognosis of the replantation of avulsed teeth. J Periodontol. 2009;80:1121-4. 16- Sakai VT, Magalhães AC, Pessan JP, Silva SMB, Machado MAAM. Urgency treatment profile of 0 to 15 year-old children assisted at urgency dental service from Bauru Dental School, University of São Paulo. J Appl Oral Sci. 2005;13(4):340-4

17- Sandalli N, Cildir S, Guler N. Clinical investigation of traumatic injuries in Yeditepe University, Turkey during the last 3 years. Dent Traumatol. 2005;21:188-94.

18- Scariot R, Oliveira IA, Passeri LA, Rebellato NLB, Müller PR. Maxillofacial injuries in a group of Brazilian subjects under 18 years of age. J Appl Oral Sci. 2009;17(3):195-8.

19- Shinya K, Taira T, Sawada M, Isshiki N. Facial injuries rom failling: age-dependent characteristics. Ann Plast Surg. 1993; 30:417-23.

20- Silva AC, Passeri LA, Mazonetto R, Moraes M, Moreira RWF. Incidence of dental trauma in Brazil: a 1-year evalution. Dent Traumatol. 2004;20:6-11. 